\title{
Improve Student Skill to Solve the Social Issues Through Problem Based Learning
}

\author{
Jalaluddin* \\ Biology Education Department \\ Serambi Mekkah University \\ Aceh, Indonesia \\ *jalaluddin@serambimekkah.ac.id
}

Kamaliyansyah Walil

Biology Education Department

Serambi Mekkah University

Aceh, Indonesia

kamalliansyahwalil@serambimekkah.ac.id

\author{
Siti Manyang Sari \\ Primary School Teacher Education Department \\ STKIP Bina Bangsa \\ Aceh, Indonesia \\ sitimanyangsari30@gmail.com
}

\author{
Juli Firmansyah \\ Physics Education Department \\ Serambi Mekkah University \\ Aceh, Indonesia \\ juli.firmansyah@serambimekkah.ac.id
}

\begin{abstract}
This research aimed at examining the effectiveness of Problem-Based Learning in improving the elementary school students' skill in solving social issues in Social Science subject. The participants were the fourth-grade students of SDN 10, Banda Aceh. The research was an action research with qualitative method. The data were collected by means of direct observations on the teacher and student activities in the classroom, as well as by test. Having applied the Problem-Based Learning, it was found that there was a significant improvement in the students' ability in solving the social issues in Social Science subject. In Cycle I, the average test score of the students was 67,50; in Cycle II, the average score increased to 74,17; and in Cycle III, it rose to 81,67, which was achieved by 22 students $(91,67 \%)$. Based on the finding, it was suggested that ProblemBased Learning is effective in improving students' learning skill in Social Science.
\end{abstract}

Keywords—problem-based learning, social issues, students' learning skills

\section{INTRODUCTION}

Characteristics of social studies learning concerns human problems as social beings who have values, norms and attitudes in society, where the embodiment of these values, norms and attitudes is more focused on the actualization that exists in the society $[1,2]$. While social studies material has experienced extraordinary developments at this time, the development of science and technology that has driven the acceleration of the realization of the Information Society has had a major impact on thinking and discussion and the development of social issues has become a very interesting. The Social Studies is no longer possible to be given conventionally, there needs to be a change in which students are the main role in the class, while the teacher's role is as a facilitator, motivator, inspirator, and evaluator [3].

From the results of previous research on social studies learning [3] it was found that most students had difficulty understanding the material being taught. This is because students are not actively involved in the learning process. The average score of students in the social studies subject is 60.67 , which indicates that students have not been able to achieve classical completeness in social studies.

One of the efforts to improve students' abilities is to use an appropriate learning model [4]. Problem-based learning model is a learning model that uses real-world problems as a learning context about critical thinking and problem-solving skills, as well as obtaining essential knowledge and concepts from subjects [5]. Several stages of the Problem Based Learning (PBL) model, namely: the initial stage of the implementation of learning, students are given problems by the teacher, second learning, during the implementation of learning students complete them and the third stage students integrate knowledge into the form reports $[6,7]$.

Social problems are one of the social studies learning materials at the elementary school level. Materials that display simple concepts and phenomena can be observed and are often found in everyday life. By applying the problem-based learning model, the teacher tries to show students social problems that are close, concrete and directly related to students' daily experiences [8]. his research was conducted to test the effectiveness of the PBL model in improving students' abilities in solving social issues in everyday life 


\section{METHODS}

\section{A. Design and Type of Reasearh}

This research is designed to solve learning problems encountered by teachers and students in the classroom. The type of research used is classroom action research with cycle stages.

Each cycle has four main stages, namely (1) design, including initial planning activities before conducting research, formulating problem formulations, objectives and making action plans including research instruments and learning tools. (2) Actions include actions taken by researchers in an effort to build students' understanding of concepts and observe the results or impacts of applying problem-based learning models. (3) Observation includes observations of the activities carried out by researchers and students in the learning process using a problem-based learning model. (4) Reflection, the researcher examines, sees and weighs the results or impacts of the actions taken based on the observation sheet filled out by the observer, $[9,10]$.

As in figure 1 , observations are divided into three rounds, namely cycles I, II and III where each round is given the same treatment (the same activity flow) and discusses one subsubject which ends with a formative test at the end of each round. This cycle is continuous and will be stopped if it is in accordance with the needs and it is felt that it has met the specified completeness criteria [11].

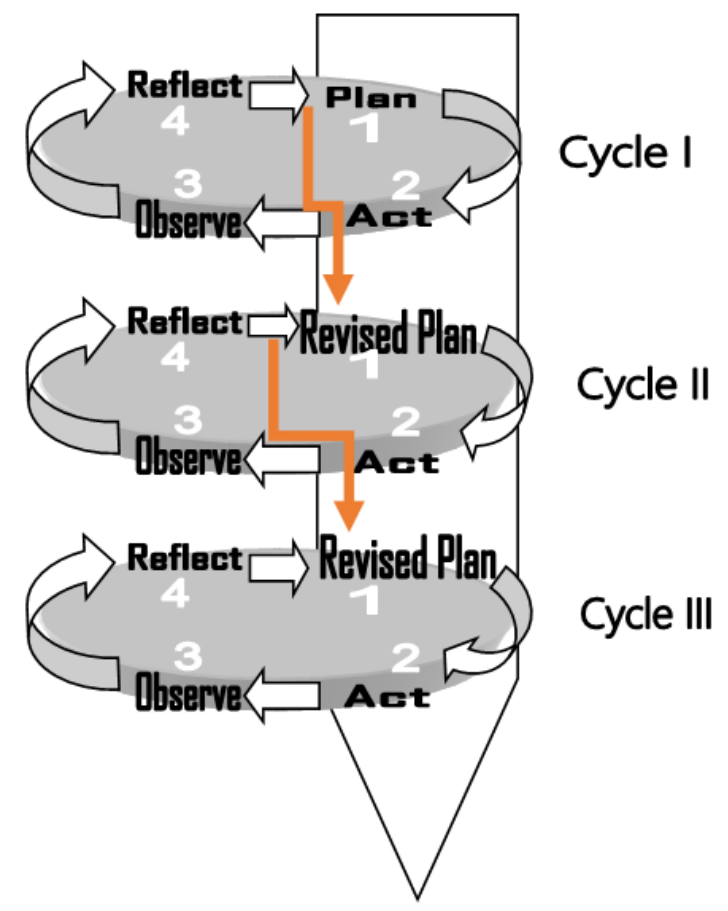

Fig. 1. Classroom action research stage.

\section{B. Research Objects and Locations}

The research was conducted at one of the elementary schools in the city of Banda Aceh which involved 22 fourth grade students.

\section{Data Collection and Analysis}

Data processing is done by calculating the average value, the percentage of student learning completeness, student, and teacher activities. The criteria for student learning completeness are based on the following conditions: (a) Students are said to have completed learning individually if they have an absorption capacity of $\geq 65 \%$ (b) Mastery of classical learning is achieved if $\geq 85 \%$ of students in the class have finished learning.

\section{RESULTS AND DISCUSSION}

The research analysis was conducted by using the descriptive statistics, namely describing the description of the results of observations of teacher and student activities using a problem-based learning model. learning outcome test data in the form of descriptions of the average score, presentation, and completeness individually and classically.

\section{A. The Research First Cycle Results}

In the first cycle of learning, the application of the problembased learning model has been applied with the achievement of the success of the application of learning in the good category, this finding is known from the activities of teachers who get a score of $73.33 \%$ and student activities and get a score of $72.50 \%$. The average score that has been obtained is 67.50 and students who have completed are 15 students $(62.50 \%)$

\section{B. The Research Second Cycle Result}

Learning in the second cycle continued because the completeness in the first cycle only reached $62.50 \%$. The success that has been achieved in cycle II shows the average score of teacher activity is $85.00 \%$ in the very good category and student activities get an average score of $90 \%$. The activities of students listening to and paying attention to the teacher's explanations and forming groups directed by the teacher are included in the very good category. Student activities in reading and doing assignments / worksheets, listening to and respecting friends' opinions, asking teachers / friends and answering quizzes / questions given by the teacher are still in good category. The average score that has been obtained is 74.17 and those who complete are 19 students (79.17\%).

\section{The Research Third Cycle Result}

The implementation of cycle III is able to improve from cycle I and cycle II. This is aimed at activities in learning that have been dominated by students where students are more active in the learning process using problem-based learning models. The successes that have been achieved in cycle III are as follows: The teacher's activity obtains an average score of 
$95 \%$, which is in the very good category. Student activities in cycle III using problem-based learning models get a score that is included in the very good category, which is $95.00 \%$. The average score that has been obtained is 81.67 and students who have completed are 19 students (91.67\%).

The discussion of the results of this study is based on the results of student learning tests followed by reflection on observations in each action cycle. In the third cycle, it was found that the fourth grades student at SD Negeri 10 Banda Aceh on the subject of social problems had accomplished both individually and classically.

Teacher activity also increased from cycle I to cycle III. This can be seen from the average value in cycle I which was obtained at $73.33 \%$ in cycle II was $85.00 \%$ and in cycle III was $95.00 \%$. The teacher's activities in delivering lessons are in accordance with the plans prepared and reflect the use of problem-based learning models.

It can be seen from the way teachers carry out learning activities such as teachers interacting with students, conveying learning objectives to students, teachers getting involved with students who are constructing their knowledge and giving students confidence that they can learn. The recapitulation of student activities can be seen in Figure 2

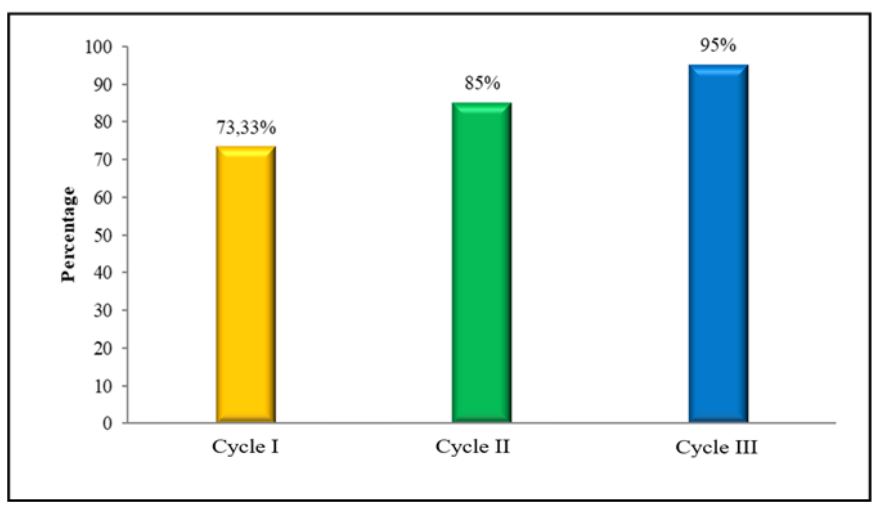

Fig. 2. Chart of teacher activity percentage recapitulation. Source: research results.

Student activity also increased from cycle I to cycle III. This can be seen from the average score in the first cycle which was obtained at $72.50 \%$ in the second cycle was $90.00 \%$ and in the third cycle it was $95.00 \%$. In learning with the use of a problem-based learning model, students are more active in the learning process, while the teacher provides direction and supervises them in conducting discussions to find a better understanding of the material taught by the teacher.

Learning outcomes in cycle I, students get a class average score of 67.50 and students who complete the learning process as many as 15 students $(62.50 \%)$ from 24 students in that class. In Cycle II, the class average score achieved by students was 74.17 and students who completed the learning process were 19 students (79.17\%) from 24 students who participated in the learning process.
In cycle III, the average score obtained by students was 81.67 which was completed by 22 students $(91.67 \%)$ of the 24 students who participated in the learning process

So that the learning atmosphere in the classroom becomes more active. Recapitulation of student activities can be seen in the following Figure 3:

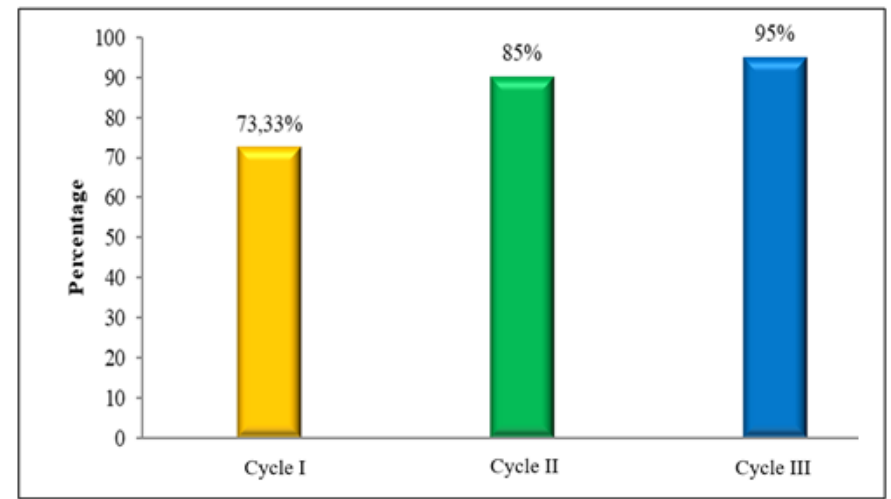

Fig. 3. Graph of the recapitulation of the average value of student activities (Source: research results).

The increase in the percentage of student completeness can be seen in the following Table I:

TABLE I. THE INCREASE OF STUDENT COMPLETENESS

\begin{tabular}{|l|l|l|l|l|}
\hline \multirow{2}{*}{ No. } & \multirow{2}{*}{ Completeness } & \multicolumn{3}{|c|}{ Percentage (\%) } \\
\cline { 3 - 5 } & & Cycle I & Cycle II & Cycle III \\
\hline 1 & Completed & 62.50 & 79.17 & 91.67 \\
\hline 2 & Uncompleted & 37.50 & 20.83 & 8.33 \\
\hline \multicolumn{2}{|r|}{ Total } & 100 & 100 & 100 \\
\hline
\end{tabular}

The researcher also describes the students' completeness in learning in each cycle as seen in the following Figure 4:

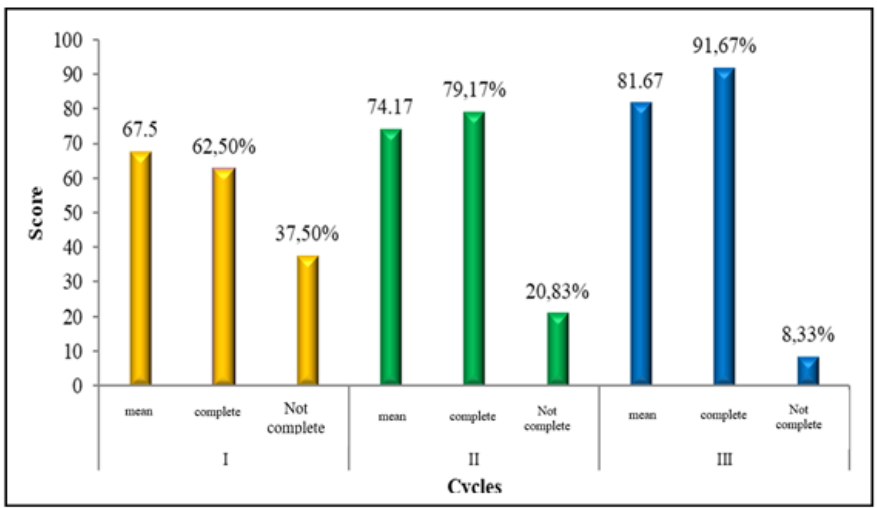

Fig. 4. Graph of average value recapitulation and compliance percentage learning outcomes.

The improvement of learning outcomes in cycle III is better than in cycles II and I, this is because the author has improved the process of applying problem-based learning models in teaching social problems. The author further improves the process of using the problem-based learning model by directing 
students in learning and better monitoring than the previous cycle, so that the completeness of learning outcomes in cycle III can be achieved properly.

The increase in learning outcomes experienced by students provides a significant change in the ability to increase students. This is due to the use of problem-based learning models. Problem-based learning tries to help students become independent and autonomous learners [12,13]. Furthermore, with teacher guidance repeatedly encouraging and directing them to ask questions, seeking solutions to real problems by themselves, students learn to complete the tasks themselves [14]. In addition, in student learning is linked to authentic problems. Authentic problems can be interpreted as problems that are often encountered by students in daily life.

Through Problem Based Learning students are trained to compile their own knowledge, develop problem solving skills, be independent and increase self-confidence [15]. In addition, by providing authentic problems, students can shape the meaning of the learning material through the learning process and store it in memory so that it can be used at any time [16].

Teacher and student activities also increased from cycle I to cycle III. Likewise, student learning outcomes have increased from cycles I, II and III. This is due to the use of problembased learning models in the learning process [17].

\section{CONCLUSION AND SUGGESTIONS}

\section{A. Conclusions}

Based on the results of research and discussion conducted by the writer on grade IV students at SDN 10 Banda Aceh using a problem-based learning model on social problem material, the conclusions that can be drawn are as follows: (a) Teacher activity has increased from cycle I to cycle III. This can be seen from the average value obtained in the first cycle of $73.33 \%$ in the second cycle of $85 \%$ and $95 \%$ in the third cycle. (b) Student activity has increased from cycle I to cycle III. This can be seen from the average score in cycle I which was obtained at $72.50 \%$ in cycle II was $90 \%$ and in cycle III was $95 \%$. In learning with the use of problem-based learning models, students are more active in the learning process. (c) Student learning outcomes have increased significantly after being taught using problem-based learning models on social problem material. In cycle I, students get a class average score of 67.50, cycle II, the average value achieved is 74.17 and cycle III, the average value obtained by students is 81.67 which is completed by 22 students $(91.67 \%)$.

\section{B. Suggestions}

The good student learning outcomes are highly expected by all parties, both from students, teachers, school principals and parents. Therefore, in the learning process students should make use of the methods / techniques and approaches provided by the teacher, so that learning outcomes can be achieved in accordance with learning objectives. In the learning process, student activities should be in accordance with problem-based learning steps. So that learning objectives can be achieved properly at the end of learning. In teaching students, grade IV teachers at SDN 10 Banda Aceh implement the use of problembased learning models for students in teaching social studies lessons in schools. The learning activities that conducted must be in accordance with the existing stages.

\section{ACKNOWLEDGMENTS}

We would like to thank the school and related institutions for providing the opportunity to conduct research.

\section{REFERENCES}

[1] J. Brophy, "Teaching Social Studies for Understanding and HigherOrder Applications,” Elem. Sch. J., vol. 90, no. 4, pp. 351-417, 1990.

[2] A. Abida Ferindistika Putri, A. Ferindistika Putri, H. Andriningrum, S Khusnul Rofiah, and I. Gunawan, "Teacher Function in Class: A Literature Review,” Adv. Soc. Sci. Educ. Humanit. Res., vol. 382, no. Icet, pp. 5-9, 2019.

[3] M.P. Scholar, "Effectiveness of Teaching Social Studies For Developing Higher,” Int. J. Res. Econ. Soc. Sci., vol. 5, no. 12, pp. 19-25, 2015.

[4] J. Dunlosky, K. A. Rawson, E. J. Marsh, M. J. Nathan, and D. T. Willingham, "Improving students' learning with effective learning techniques: Promising directions from cognitive and educational psychology," Psychol. Sci. Public Interes. Suppl., vol. 14, no. 1, pp. 4 58, 2013.

[5] M.N.M. Zabit, "Problem-Based Learning On Students Critical Thinking Skills In Teaching Business Education In Malaysia: A Literature Review,” Am. J. Bus. Educ., vol. 3, no. 6, pp. 19-32, 2010.

[6] I.N. Dwi and S. W. Anitah, "The Implementatyion Off Problem Based Learning Model (PBL) on Teachers and Students Grade Five Elementary Schools in Surakarta City," Int. J. Act. Learn., vol. 3, no. 2, pp. 116-123, 2018.

[7] R. Phungsuk, C. Viriyavejakul, and T. Ratanaolarn, "Development of a problem-based learning model via a virtual learning environment," Kasetsart J. Soc. Sci., vol. 38, no. 3, pp. 297-306, 2017.

[8] N.C. Chen, "An educational approach to problem-based learning," Kaohsiung J. Med. Sci., vol. 24, no. 3 SUPPL., pp. 23-30, 2008.

[9] C. Chin and J. Osborne, "Students' questions: A potential resource for teaching and learning science," Stud. Sci. Educ., vol. 44, no. 1, pp. 1-39, 2008.

[10] D.H.E. Ahtaridou, A teacher's guide to classroom research. aidenhead Open University Press, 2008.

[11] P. Riding, S. Fowell, and P. Levy, "An action research approach to curriculum development," Inf. Res. an Int. Electron. J., vol. 1, no. 1, p. 2, 1995.

[12] T. McCarthy, "Integrating project-based learning into a traditional skillsbased curriculum to foster learner autonomy: An action research," J. Kanda Univ. Int. Stud., vol. 22, pp. 221-244, 2010.

[13] N.S. Masouleh and R.B. Jooneghani, "Autonomous learning: A teacherless learning!,” Procedia - Soc. Behav. Sci., vol. 55, pp. 835-842, 2012.

[14] B. Aidoo, S.K. Boateng, P.S. Kissi, and I. Ofori, "Effect of ProblemBased Learning on Students' Achievement in Chemistry," J. Educ. Pract., vol. 7, no. 33, pp. 103-108, 2016.

[15] R. Ramadhani, S. Huda, and R. Umam, "Problem-Based Learning, Its Usability and Critical View as Educational Learning Tools," J. Gift. Educ. Creat., vol. 6, no. 3, pp. 219-231, 2019.

[16] C.E. Hmelo-Silver, "Problem-based learning: What and how do students learn?" Educational psychology review, vol. 16, no. (3), pp. 235-266, 2004.

[17] Nurzaman, "The Use of Problem-Based Learning Model to Improve Quality Learning Students Morals,” J. Educ. Pract., vol. 8, no. 9, pp. 234-248, 2017. 